\title{
SINGLE-SAMPLE TESTS IN THE DIFFERENTIAL DIAGNOSIS OF JAUNDICE
}

\author{
B' \\ C. A. MAWSON \\ From the Pathological Laboratory, Royal Berkshire Hospital, Reading
}

(RECEIVED FOR PUblication, JANUARY 16, 1948)

Many attempts have been made to compare the usefulness of the various tests of liver function. The papers of White and others (1940), Wilson (1940), Higgins and others (1944), Maizels (1946), and Sherlock (1946) discuss the merits of such diverse estimations as bromsulphalein, hippuric acid, and urobilinogen excretion ; bilirubin, cholesterol, cholesterol esters, differential proteins, fibrinogen, phosphatase, phospholipins, and prothrombin in serum or plasma; galactose and fructose tolerance ; and the cephalin-cholesterol, colloidal red, Takata-Ara, and thymol turbidity tests. It has been difficult to find an independent measure of the degree of liver damage, and even the liver biopsy used by Sherlock and others may not always be satisfactory. If the tests are regarded as empirical aids in specific diagnostic problems, rather than as a means of measuring liver damage, the situation is simplified, though the evaluation of results must often depend upon the accuracy of clinical diagnosis.

The object of the present work has been to investigate the suggestion of Maclagan (1944a) that a combination of the thymol turbidity or the colloidal gold test with an estimation of the serum alkaline phosphatase would distinguish between infective hepatitis and obstructive jaundice in a high proportion of cases. Maclagan (1947) has published a survey of his results using these tests on two hundred cases of jaundice, of which fiftysix were obstructive and ninety-five infective hepatitis. He was able to distinguish between obstructive and non-obstructive jaundice in from 65 to 79 per cent of cases by combining one flocculation test with an estimation of the serum alkaline phosphatase. The limits set for the data to be considered of diagnostic significance were so severe as to exclude the possibility of misclassification within his group of cases. In practical work it is usual to accept some possibility of error as inevitable, and with this in mind Maclagan's results are very satisfactory. Rennie and Rae $\mathbf{N}^{*}$
(1947) have reported their experience with the cephalin-cholesterol and colloidal gold tests in obstructive jaundice, infective hepatitis, and several other diseases involving liver injury. They showed that these two flocculation tests gave negative results in 84 per cent of cases of obstructive jaundice while positive flocculations were obtained with nearly as high a proportion of sera from patients with infective hepatitis. These authors point out that in spite of general agreement between the results of the two tests they were not always parallel, and a similar lack of strict correlation has been observed among the flocculation tests used in the present investigation.

In addition to the thymol turbidity and colloidal gold tests the present investigation has included Britton's (1945) modification of the Takata-Ara reaction, together with the estimation of the alkaline phosphatase, bilirubin, and albumin-globulin ratio. These six tests can all be performed on $3.5 \mathrm{ml}$. serum and have in this respect an advantage over the tolerance tests, which involve several venepunctures. The results have been analysed statistically by methods described by Bradford Hill (1946).

\section{Experimental \\ METHODS}

All colours and turbidities were read in a King (1942) photo-electric colorimeter, using Ilford spectrum light filters.

Takata-Ara reaction.-The modified method of Britton (1945) was used. Three tubes containing respectively $1 \mathrm{ml}$. of $1: 2,1: 4$, and $1: 8$ dilutions of serum in 0.85 per cent $\mathrm{NaCl}$ were treated with $0.25 \mathrm{ml}$. 10 per cent $\mathrm{Na}_{2} \mathrm{CO}_{3}$ and $0.3 \mathrm{ml}$. 0.5 per cent $\mathrm{HgCl}_{2}$. The tubes were shaken after each addition and examined after twenty-four hours. The amount of precipitate in each tube was graded as $3,2,1$, or 0 , corresponding to the more usual notation of,+ \pm , trace, and $\theta$. This device was adopted for statistical reasons, the result of the test being obtained by totalling the grades of the three tubes. 
Colloidal gold test.-The method and grading of results were those of Maclagan (1944b).

Thymol turbidity test.-Maclagan's method (1944a) was used. The buffer made up as described by Maclagan gave a $p H$ of less than 7.8 , so the $p H$ was adjusted to this value with $\mathrm{NaOH}$. It was later found that this led to a reduction in sensitivity, but for purposes of comparison it was considered inadvisable to alter the procedure in the middle of the investigation.

Alkaline phosphatase.-This was estimated by the method of King and others (1942).

Differential serum proteins. - The biuret method of Robinson and Hogden (1940) was used for total proteins and albumin.

Bilirubin.-This was estimated by the method of King and others (1937).

\section{Results \\ Normal Blood Donors}

The three flocculation tests have been carried out on the sera of one hundred apparently normal blood donors, and the results are shown in Table 1 . (The large number of significant figures given in this and other tables are included for statistical purposes and not because they are supposed to have physical significance.) It has been assumed that the "normal range" is given by the mean \pm twice the standard deviation. When a result outside the normal range was obtained with one of the flocculation tests on the serum of a normal blood donor the other two tests were usually normal.

TABLE I

RESULTS OF FLOCCULATION TESTS ON ONE HUNDRED SERA FROM NORMAL BLOOD DONORS

\begin{tabular}{ll|c|c|c}
\hline \multicolumn{1}{c|}{ Test } & Mean & $\begin{array}{c}\text { Standard } \\
\text { deviation }\end{array}$ & $\begin{array}{c}\text { Mean } \pm \\
2 \times \text { S.D. }\end{array}$ \\
\hline Takata-Ara .0 & $\ldots$ & 0.4 & 0.92 & $0-2$ \\
Colloidal gold & $\ldots$ & 0.3 & 0.81 & $\begin{array}{c}0-2 \\
0.1-2.3\end{array}$ \\
Thymol turbidity & $\cdots$ & 1.2 & 0.53 & \\
\hline
\end{tabular}

S.D. = standard deviation.

Flocculation tests and albumin-globulin ratio. - It has been stated by Bálint and Bálint (1942) that positive results in the Takata-Ara reaction are merely due to an abnormally low albumin-globulin ratio, and in particular to a relative excess of " euglobulin," which includes the fraction now referred to as $\gamma$-globulin. It was - thought useful to compare the results of all three floeculation tests with those of differential serum protein estimations, and correlation coefficients have been calculated between the individual flocculation tests and between these tests and
TABLE II

CORRELATION COEFFICIENTS OF FLOCCULATION TESTS WITH ALBUMIN-GLOBULIN RATIO, AND OF FLOCCULATION TESTS WITH ONE ANOTHER

\begin{tabular}{|c|c|c|c|}
\hline Correlation & $\begin{array}{c}\text { Number } \\
\text { of } \\
\text { tests (n) }\end{array}$ & $\begin{array}{c}\text { Correlation } \\
\text { coefficient } \\
(\mathrm{r})\end{array}$ & $\begin{array}{l}\text { "Significance" } \\
\left(\mathrm{r} / \sqrt{\frac{1}{n-1}}\right)\end{array}$ \\
\hline $\begin{array}{l}\text { Gold-A/G } \\
\text { Thymol-A/G } \\
\text { Takata-A/G } \\
\text { Takata-Thymol } \\
\text { Takata-Gold } \\
\text { Thymol-Gold }\end{array}$ & $\begin{array}{l}187 \\
187 \\
186 \\
352 \\
320 \\
315\end{array}$ & $\begin{array}{r}0.22 \\
-0.23 \\
+0.38 \\
+0.49 \\
+0.61 \\
+0.77\end{array}$ & $\begin{array}{r}3.0 \\
3.1 \\
5.2 \\
9.2 \\
10.8 \\
13.7\end{array}$ \\
\hline
\end{tabular}

the albumin-globulin ratio. Pathological sera 0 were used, and the results are shown in Table II.

The correlation coefficient divided by its $\operatorname{stan}-\vec{z}$ dard error (col. 4) is in each case greater than 2 and is therefore significant. This does not prove, however, that positive flocculation tests are due to a common cause, and still less does it prove that the cause is a low albumin-globulin ratio. The lowest correlation coefficients in the table are those between the albumin-globulin ratio and the flocculation tests, and the highest correla- $\stackrel{\circ}{\circ}$ tion is between the colloidal gold and thymol tur- $\stackrel{\AA}{2}$ bidity tests. A reduced albumin-globulin ratio is $\overrightarrow{\vec{O}}$ more closely associated with a positive Takata-Ara 3 reaction than with high results in the colloidal gold $\supset$ and thymol turbidity tests, and this point will be? referred to in the discussion.

Infective HePatitis and Obstructive Jaundice

Flocculation tests and proteins.-A comparison $\delta$ between results from patients with infective hepa- $₹$ titis, diagnosed clinically, with those from cases 0 of obstructive jaundice proved at operation or necropsy, is shown in Table III. If a series of investigations had been done on the same patient the first complete set was used for the statistical o analysis. It has been assumed that the difference $N$ between two means $(\bar{x}-\bar{y})$ is significant if $\bar{x}-\bar{y} N_{\mathcal{W}}$ divided by the standard error of the difference (S.E.) is greater than 2. While all 3 flocculation tests gave significant differences in the two forms $\frac{D}{\Phi}$ of jaundice the colloidal gold and thymol turbidity $\stackrel{0}{+}$ tests gave much better discrimination than the 0 Takata-Ara reaction.

The serum proteins and albumin-globulin ratio were almost identical in the two forms of jaundice.

Bilirubin and phosphatase. -The mean serum bilirubin in infective hepatitis $(6.8 \mathrm{mg} . / 100 \mathrm{ml}$.) was significantly lower than that obseryed in obstructive jaundice $(12.2 \mathrm{mg}$. $/ 100 \mathrm{ml}$.), but the 
TABLE III

COMPARISON BETWEEN RESULTS IN INFECTIVE HEPATITIS AND IN OBSTRUCTIVE JAUNDICE

\begin{tabular}{|c|c|c|c|c|c|c|c|c|c|c|}
\hline & & 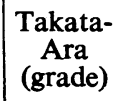 & $\begin{array}{c}\text { Colloidal } \\
\text { gold } \\
\text { (grade) }\end{array}$ & $\begin{array}{c}\text { Thymol } \\
\text { turbidity } \\
\text { (units) }\end{array}$ & $\begin{array}{l}\text { Total } \\
\text { protein } \\
(\%)\end{array}$ & $\underset{(\%)}{\text { Albumin }}$ & $\begin{array}{c}\text { Globulin } \\
(\%)\end{array}$ & $\begin{array}{l}A / G \\
\text { ratio }\end{array}$ & $\begin{array}{c}\text { Alkaline } \\
\text { phosphatase } \\
\text { (units/100 ml.) }\end{array}$ & $\underset{(\mathrm{mg} . / 100 / \mathrm{ml} .)}{\text { Bilirubin }}$ \\
\hline $\begin{array}{l}\text { Infective } \\
\text { hepatitis }\end{array}$ & $\left\{\begin{array}{c}n \\
\bar{x} \\
\text { S.D. }\end{array}\right.$ & $\begin{array}{c}37 \\
4.49 \\
2.22\end{array}$ & $\begin{array}{c}32 \\
2.84 \\
1.73\end{array}$ & $\begin{array}{c}37 \\
4.81 \\
2.99\end{array}$ & $\begin{array}{c}28 \\
6.44 \\
0.93\end{array}$ & $\begin{array}{c}28 \\
3.25 \\
0.90\end{array}$ & $\begin{array}{c}28 \\
3.20 \\
0.97\end{array}$ & \begin{tabular}{|c|}
28 \\
1.14 \\
0.47 \\
\end{tabular} & $\begin{array}{c}38 \\
17.59 \\
7.94\end{array}$ & $\begin{array}{c}36 \\
6.80 \\
5.67\end{array}$ \\
\hline $\begin{array}{l}\text { Obstructive } \\
\text { jaundice }\end{array}$ & $\left\{\begin{array}{c}\mathrm{n} \\
\overline{\mathrm{y}} \\
\text { S.D. }\end{array}\right.$ & $\begin{array}{c}34 \\
2.06 \\
2.14 \\
\end{array}$ & $\begin{array}{c}31 \\
0.06 \\
0.25\end{array}$ & $\begin{array}{c}34 \\
0.78 \\
0.49 \\
\end{array}$ & $\begin{array}{c}25 \\
6.18 \\
0.67 \\
\end{array}$ & $\begin{array}{r}25 \\
3.12 \\
0.56 \\
\end{array}$ & $\begin{array}{l}25 \\
3.05 \\
0.55\end{array}$ & \begin{tabular}{|c|}
25 \\
1.05 \\
0.29
\end{tabular} & $\begin{array}{c}33 \\
37.85 \\
16.36 \\
\end{array}$ & $\begin{array}{r}34 \\
12.19 \\
9.45 \\
\end{array}$ \\
\hline $\begin{array}{l}\text { Analysis } \\
\text { of } \\
\text { differences }\end{array}$ & $\left\{\begin{array}{l}\overline{\bar{x}-\bar{y}} \\
\text { S.E. } \\
\overline{\bar{x}-\bar{y}} \\
\overline{\text { S.E. }}\end{array}\right.$ & $\begin{array}{l}2.43 \\
0.52 \\
4.7\end{array}$ & $\begin{array}{l}2.78 \\
0.31 \\
9.0\end{array}$ & $\begin{array}{l}4.03 \\
0.50 \\
8.1\end{array}$ & $\begin{array}{l}0.26 \\
0.23 \\
1.2\end{array}$ & $\begin{array}{l}0.13 \\
0.20 \\
0.7\end{array}$ & $\begin{array}{l}0.16 \\
0.21 \\
0.8\end{array}$ & \begin{tabular}{|l|}
0.09 \\
0.11 \\
0.8
\end{tabular} & $\begin{array}{l}20.26 \\
3.13 \\
6.5\end{array}$ & $\begin{array}{l}3.3 y \\
1.88 \\
2.9\end{array}$ \\
\hline
\end{tabular}

$\mathrm{n}=$ Number of patients. $\overline{\mathrm{x}}$ and $\overline{\mathrm{y}} \doteq$ mean values. S.D. $=$ standard deviation. S.E. $=$ standard error of difference between means. A/G = albumin-globulin.

serum alkaline phosphatase was of much greater discriminant value than the bilirubin.

Sherlock (1946) found that no positive correlation existed between the bilirubin and phosphatase contents of the serum in obstructive jaundice and infective hepatitis. This observation has been confirmed by the present work. In obstructive jaundice the correlation coefficient was 0.29 , and the coefficient divided by its standard error was only 1.63 , indicating that the correlation was not significant. The corresponding figures for infective hepatitis were 0.17 and 1.00 . The number of cases on which these figures are based (72), combined with those of Sherlock, makes it virtually certain that bilirubin and phosphatase are not secreted into the serum by the same mechanism, which supports Maclagan's (1947) view that the rise in phosphatase " represents a positive secretory response of the liver cell to a variety of chemical or bacterial insults." An alternative explanation would be a difference in the mechanism of the removal of these substances from the plasma.

Relative discriminant value of tests.-If we regard $(\bar{x}-\bar{y}) / S . E$. as a measure of the relative discriminant values of the tests, the descending order of usefulness given by the figures in Table III is: colloidal gold, thymol turbidity, phosphatase, Takata-Ara, and bilirubin. Maclagan (1947) found that the alkaline phosphatase had the highest discriminant value, followed by thymol flocculation, colloidal gold, and thymol turbidity. Unfortunately the thymol flocculation was not recorded frequently enough in the present work for adequate statistical treatment.

\section{Miscellaneous Diseases}

Although many pathological sera have been examined the number for each disease has been small except for infective hepatitis and obstructive jaundice. Malaria and infective mononucleosis, and to a lesser extent amoebic hepatitis and thyrotoxicosis, have given positive flocculation tests, while extensive carcinomatous metastases in the liver and almost total destruction of normal hepatic tissue in Banti's disease have given results within normal limits.

\section{Discussion}

Takata-Ara reaction.- In the series of eightyone cases considered by Bálint and Bálint (1942), positive results in the Takata-Ara reaction were nearly always associated with a lowered albuminglobulin ratio. Only six anomalous results were obtained-four sera with albumin-globulin ratios of 1.3 to 1.6 gave positive results, whereas no flocculation was observed with two sera having albumin-globulin ratios of 1.1. Although the present results show a highly significant correlation $(-0.38)$ between the Takata-Ara reaction and the albumin-globulin ratio, there were many examples in -which the results were not parallel. Among 188 sera, twenty-eight had a Takata-Ara-reaction lower than grade 2, coupled with albuminglobulin ratios below 1.2, and on the other hand Takata-Ara reactions higher than Grade 2 occurred with twenty-four sera having albumin-globulin ratios higher than 1.2. Britton's Takata-Ara reaction cannot therefore be regarded merely as a qualitative indication of lowered albumin-globulin ratio. 
Colloidal gold and thymol turbidity tests.There is disagreement concerning the mechanism of the flocculation tests, particularly regarding the thymol turbidity test. The evidence was reviewed by Maclagan and Bunn (1947), who found that $\gamma$-globulins were the main precipitating proteins in the thymol, gold, cephalin-cholesterol, and TakataAra tests. The cephalin-cholesterol and TakataAra reagents were also precipitated by $a-$ and $\beta$-globulins from hepatitis sera. The gold test was inhibited by albumin and $\alpha$ - and $\beta$-globulins, while albumin inhibited the cephalin-cholesterol and Takata-Ara reactions. Cohen and Thompson (1947) believe that although the $\gamma$-globulins are raised in hepatitis sera while the $\beta$-globulins may only be slightly above normal, nevertheless a high thymol turbidity is probably due to a qualitative change in the $\beta$-globulin fraction. Unfortunately the conditions used by Cohen and Thompson were not the same as those specified by Maclagan.

The present investigation shows that the colloidal gold and thymol turbidity tests are not measures of exactly the same phenomenon. The correlation coefficient of +0.77 between these two tests (Table II) is high, but in many individual cases they gave discordant results. Among 323 pathological sera, twenty gave abnormally high thymol turbidities combined with normal "golds," whereas eight had high "golds" with normal " thymols." Thus in about 9 per cent of these sera the results of the two tests were not in agreement, which would be unlikely if both depended on the same set of conditions. The flocculation is probably due in both cases to the same positive cause (e.g., $\gamma$-globulins), but the modifying factors such as albumin and $\alpha_{-}$and $\beta$-globulins are different (Maclagan and Bunn, 1947; Moore and others, 1945). The danger of drawing sweeping conclusions from comparisons between parallel results of these empirical tests is illustrated by the fact that slight variations in reagents and technique may give very different results with the same serum.

The technical difficulty of fractionating sera electrophoretically is a serious obstacle to quantitative investigation of the flocculation tests. The work of Maclagan and Bunn (1947) was based upon results from a single mixed specimen of " typical" hepatitis serum, and the limitation which this places upon their interpretations will be realized when it is considered that in a series of cases of "typical" infective hepatitis the results of the various flocculation tests may range from all being strongly positive to an occasional example in which all are negative (Tables IV and V).
TABLE IV

ANOMALOUS RESULTS IN INFECTIVE HEPATITIS

\begin{tabular}{|c|c|c|c|c|c|c|}
\hline No. & $\begin{array}{l}\text { Takata } \\
\text { (grade) }\end{array}$ & $\begin{array}{c}\text { Gold } \\
\text { (grade) }\end{array}$ & $\begin{array}{l}\text { Thy- } \\
\text { mol } \\
\text { (units) }\end{array}$ & $\mathrm{A} / \mathrm{G}$ & $\begin{array}{c}\text { Alkaline } \\
\text { phospha- } \\
\text { tase } \\
\text { (units/ } \\
100 \mathrm{ml} \text {.) }\end{array}$ & $\begin{array}{c}\text { Bili- } \\
\text { rubin } \\
\text { (mg./ } \\
100 \mathrm{ml} .\end{array}$ \\
\hline 1 & 1 & 1 & 1.8 & 2.1 & 10.0 & 5.5 \\
\hline 2 & 2 & 0 & 0.9 & 0.9 & 1. & $4: 3$ \\
\hline 3 & 0 & 0 & 0.4 & 2.4 & 33.2 & 6.1 \\
\hline 4 & 3 & 0 & 1.4 & 1.2 & 13.6 & 1.4 \\
\hline 5 & 0 & 1 & 1.8 & - & 17.4 & 6.0 \\
\hline 6 & 0 & 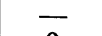 & 1.1 & - & 19.6 & 3.6 \\
\hline 7 & 3 & 0 & 3.2 & 1.4 & 16.5 & 21.0 \\
\hline 8 & 5 & 0 & - & 1.5 & 13.4 & \\
\hline 9 & 5 & 3 & 2.1 & 1.3 & 16.4 & 9.7 \\
\hline 10 & 2 & 2 & 2.1 & 1.6 & 9.7 & 4.1 \\
\hline 11 & 3 & & 1.6 & - & 12.5 & 4.6 \\
\hline 12 & 5 & - & 2.1 & - & 24.0 & 2.5 \\
\hline
\end{tabular}

Differential diagnosis of jaundice.-A compari- $\vec{e}$ son is shown in the Figure between the results. obtained with the three flocculation tests when applied to sera from normal blood donors and from patients with obstructive jaundice and infective hepatitis. The means are shown at the corners of the triangles, and in the middle of each side is $\stackrel{\mathbb{\Omega}}{\Omega}$ given the "significance" $(\bar{x}-\bar{y} /$ S.E. $)$ of the differ $-\overrightarrow{\vec{F}}$ ence between the means at the corresponding 3 corners. The Takata-Ara reaction in both forms?

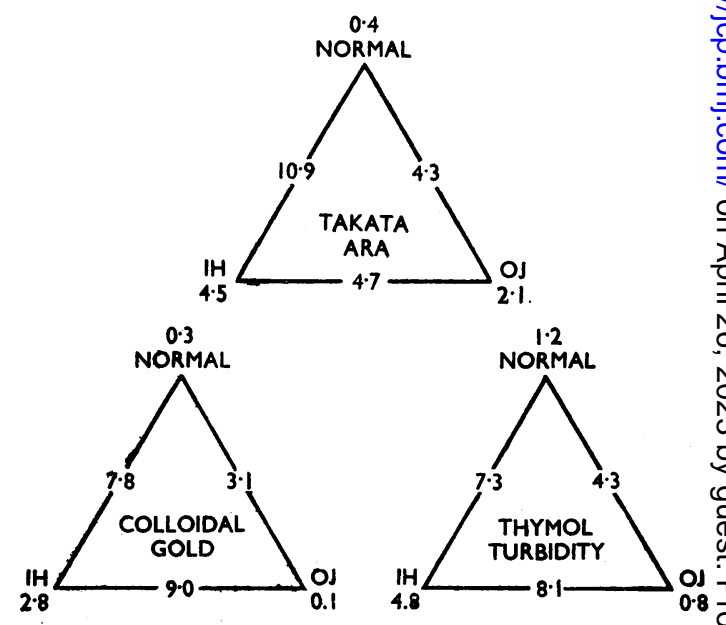

FIGURE.-Differences between results of flocculation

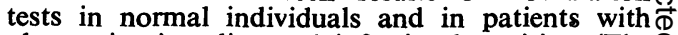
obstructive jaundice and infective hepatitis. (The figures at the corners of the triangles are means, and those on the sides represent significance of differences between means.) 
of jaundice was significantly above the normal, which is consistent with the fact that liver damage occurs in both conditions. However, in the case of the thymol turbidity and colloidal gold tests the results in obstructive jaundice were significantly lower than the normal values. These two tests should not, therefore, be referred to as "liver function tests."

For the differentiation of obstructive jaundice from infective hepatitis these results suggest that in obstructive jaundice the colloidal gold test will be grade 0 , or occasionally grade 1 , the thymol turbidity 2.1 units or less, and the alkaline phosphatase greater than 25 units $/ 100 \mathrm{ml}$. In infective hepatitis the colloidal gold will be greater than Grade 1 , the thymol turbidity above 2.1 units, and the phosphatase less than 20 units $/ 100 \mathrm{ml}$. No case of obstructive jaundice has been encountered which would have been wrongly diagnosed using either the colloidal gold or thymol turbidity test alone with the above criteria, but among thirtynine cases diagnosed clinically as infective hepatitis no less than twelve gave misleading results with one of these flocculation tests (Table IV). In the first five cases shown in the table both tests gave results within normal limits. However, in ten of these twelve cases the phosphatase was below 20 units $/ 100 \mathrm{ml}$., whereas among thirty-three cases of proved obstructive jaundice a phosphatase of less than 20 units $/ 100 \mathrm{ml}$. only occurred five times, the lowest value observed being 16.8 units $/ 100 \mathrm{ml}$. Taking all the criteria into consideration the only cases shown in Table IV which would be likely to be wrongly diagnosed are numbers 3,6 , and 12 , and only in Case 3 are the results really typical of obstructive jaundice. Serial tests were done on seven of the twelve cases in Table IV, and three of these eventually gave positive flocculation tests.
The frequency of positive results for the TakataAra reaction in obstructive jaundice makes this test useless for the differentiation of the cases quoted in Table IV. Among thirty-three obstructive jaundice sera, fourteen gave results above Grade 2, and nine above Grade 3. It is noteworthy that the albumin-globulin ratios shown in the table are, with only one exception, within normal limits, which suggests that the liver damage could not have been severe, and in all cases except two the bilirubin is below the mean for infective hepatitis of $6.8 \mathrm{mg} . / 100 \mathrm{ml}$.

That the chance of mis-classification, using the above criteria, is real and not due to mistaken clinical diagnosis is illustrated in Table $\mathrm{V}$, which shows results from two soldiers, $A$ and $B$, who entered hospital within a few days of one another. They were close friends and slept in adjoining beds in barracks, and there seems little doubt that they had infective hepatitis of common origin. The results of the tests on the two men were very different even when done simultaneously, and, if the colloidal gold and thymol turbidity results alone had been considered, A might well have been diagnosed as suffering from obstructive jaundice. The low phosphatase made such a diagnosis unlikely, but it must be admitted that it is a mistake to place too much reliance on this test when it conflicts with the flocculation tests. In doing so one would be discarding the results of two tests of high discriminant value in favour of that of a single test of lower discriminant value (Table III).

Maclagan (1947) gave a series of criteria for discrimination which excluded all possibility of mistaken diagnosis within his group of cases. A similar classification of the results obtained in the present work shows that, in round figures, all cases with phosphatase greater than 40 units $/ 100 \mathrm{ml}$.

TABLE V

TWO CONTRASTED CASES OF INFECTIVE HEPATITIS, PROBABLY OF COMMON ORIGIN

\begin{tabular}{|c|c|c|c|c|c|c|c|c|c|c|}
\hline Case & Date & $\begin{array}{c}\text { Takata- } \\
\text { Ara } \\
\text { (grade) }\end{array}$ & $\begin{array}{l}\text { Colloidal } \\
\text { gold } \\
\text { (grade) }\end{array}$ & $\begin{array}{c}\text { Thymol } \\
\text { turbidity } \\
\text { (units) }\end{array}$ & $\begin{array}{l}\text { Total } \\
\text { protein } \\
(\%)\end{array}$ & $\begin{array}{c}\text { Albumin } \\
(\%)\end{array}$ & $\begin{array}{c}\text { Globulin } \\
(\%)\end{array}$ & $\begin{array}{l}\mathrm{A} / \mathrm{G} \\
\text { ratio }\end{array}$ & $\begin{array}{c}\text { Alkaline } \\
\text { phosphatase } \\
\text { (units/100 ml.) }\end{array}$ & $\begin{array}{c}\text { Bilirubin } \\
(\mathrm{mg} . / 100 \mathrm{ml} .)\end{array}$ \\
\hline $\mathbf{A}$ & $\begin{array}{r}1.8 .46 \\
2.8 .46 \\
7.8 .46 \\
13.8 .46\end{array}$ & $\begin{array}{l}1 \\
2 \\
1 \\
1\end{array}$ & $\begin{array}{l}1 \\
1 \\
0 \\
0\end{array}$ & $\begin{array}{l}1.8 \\
1.8 \\
1.2 \\
1.6\end{array}$ & $\begin{array}{l}8.4 \\
8.7 \\
7.5\end{array}$ & $\begin{array}{l}5.7 \\
5.8 \\
4.8\end{array}$ & $\begin{array}{l}2.7 \\
2.9 \\
\overline{2.7}\end{array}$ & $\begin{array}{l}2.1 \\
2.0 \\
\overline{1.8}\end{array}$ & $\begin{array}{c}10.0 \\
13.3 \\
\frac{8.9}{8.9}\end{array}$ & $\begin{array}{c}11.1 \\
13.5 \\
\frac{2.5}{2.5}\end{array}$ \\
\hline B & $\begin{array}{r}6.8 .46 \\
7.8 .46 \\
13.8 .46 \\
24.8 .46 \\
5.9 .46\end{array}$ & $\begin{array}{l}6 \\
6 \\
4 \\
4 \\
4\end{array}$ & $\begin{array}{l}3 \\
4 \\
5 \\
1 \\
1\end{array}$ & $\begin{array}{l}4.7 \\
4.8 \\
5.0 \\
2.4 \\
2.0\end{array}$ & $\begin{array}{l}6.8 \\
7.5 \\
6.7 \\
5.9\end{array}$ & $\begin{array}{l}4.0 . \\
3.9 \\
3.8 \\
3.8\end{array}$ & $\begin{array}{l}2.8 \\
3.6 \\
2.9 \\
2.1\end{array}$ & $\begin{array}{l}\frac{1.5}{1.1} \\
1.7 \\
1.8\end{array}$ & $\begin{array}{l}20.6 \\
\overline{17.6} \\
13.6 \\
10.9\end{array}$ & $\begin{array}{r}6.6 \\
15.0 \\
39.2 \\
4.1 \\
2.9\end{array}$ \\
\hline
\end{tabular}


were obstructive jaundice and all with phosphatase less than 17 units $/ 100 \mathrm{ml}$. were infective hepatitis. All sera having colloidal gold tests less than Grade 2 and thymol turbidities less than 2.2 units, combined with phosphatase higher than 33 units/ $100 \mathrm{ml}$., were from patients with obstructive jaundice, and all cases having colloidal gold tests greater than Grade 1 and thymol turbidities greater than 2.1 units were of infective hepatitis. These results agree well with those of Maclagan, except that Maclagan's thymol and gold reagents were evidently considerably more sensitive than those used in this investigation.

\section{Summary}

1. The usefulness of the Takata-Ara reaction, colloidal gold, and thymol turbidity tests, differential serum proteins, serum alkaline phosphatase, and serum bilirubin estimations for the differential diagnosis of infective hepatitis and obstructive jaundice has been investigated.

2. Statistical analysis indicates that all these tests except the differential serum proteins give significantly different results in the two forms of jaundice, but only the colloidal gold, thymol turbidity, and alkaline phosphatase are of high discriminant value.

3. The three flocculation tests are closely correlated with one another and, to a lesser extent, with the albumin-globulin ratio. Each is a measure of a different complex of factors, and none is merely a qualitative test for a lowered albuminglobulin ratio.

4. The Takata-Ara reaction gave results above normal in both forms of jaundice, but the mean results of the colloidal gold and thymol turbidity tests were significantly lower in obstructive jaundice than in normal sera.

5. There is no significant correlation between the bilirubin and the phosphatase in either form of jaundice.
6. All sera from patients with obstructive jaundice had colloidal gold tests less than Grade 2 and thymol turbidities less than 2.1 units, and 75 per cent had a serum alkaline phosphatase greater than 25 units $/ 100 \mathrm{ml}$. About 70 per cent. of sera from patients with infective hepatitis had colloidal gold tests greater than Grade 1, thymol turbidities greater than 2.1 units, and phosphatase less than 20 units $/ 100 \mathrm{ml}$. All cases with phosphatase greater than 40 units $/ 100 \mathrm{ml}$. were obstructive jaundice, and all with phosphatase less than 17 units $/ 100 \mathrm{ml}$. were infective hepatitis. All cases with gold tests less than Grade 2 and thymol turbidities less than 2.2 units, combined with phosphatase higher than 31 units $/ 100 \mathrm{ml}$., were obstructive jaundice.

Grateful acknowledgment is made to my medical colleagues at this hospital and at the Battle hospital, and particularly to Dr. W. Hausmann, for the supply of sera and reports. Drs. R. B. Fisher and P. White gave valuable advice on the interpretation of the statistics, and Mr. E. B. Love, B.Sc., carried out many of the estimations of phosphatase and bilirubin.

\section{REFERENCES}

Bálint, P., and Bálint, M. (1942). Biochem. Z., 313, 201.

Britton, C. J. C. (1945). Middlesex Hosp. J., 45, 29. Higgins, G., O'Brien, J. R. P., Stewart, A., and Witts, L. J. (1944). Higgins, G., O'Brien, J. R. P., Stewart, A., and Witts, L. J. (1944). Hill, A. Bradford (1946). "Principles of Medical Statistics." 3rd ed. London. Lancet, Ltd.

King, E. J. (1942). Lancet, 1, 511

King, E. J., Haslewood, G. A. D., and Delory, G. E. (1937). Lancet, 1, 886.

King, E. J., Haslewood, G. A. D., Delory, G. E., and Beall, D. (1942) Lancet, 1, 207.

Maclagan, N. F. (1944a). Brit. J. exp. Path., 25, 234

Maclagan, N. F. (1944b). Brit. J. exp. Path., 25, 15.

Maclagan, N. F. (1947). Brit. med. J., 2, 197.

Maclagan, N. F., and Bunn, D. (1947). Biochem. J., 41, 580

Maizels, M. (1946). Lancet, 2, 451.

Moore, D. B., Pierson, P. S., Hanger, F. M., and Moore, D. H. (1945). J. clin. Invest., 24, 292.

Rennie, J. B., and Rae, S. L. (1947). Brit. med. J., 2, 1030.

Robinson, H. W., and Hogden, C. G. (1940). J.biol. Chem., 135, 727. 옥

Sherlock, S. P. V. (1946). J. Path. Bact., 58, 523.

White, F. W., Deutsch, E., and Maddock, S. (1940). Amer. J. digest. Dis., 7, 3 .

Wilson, S. J. (1940). J. Lab. clin. Med., 25, 1139. 